\title{
ANALISIS SISTEM DRAINASE AKIBAT CURAH HUJAN YANG TINGGI \\ (Studi Kasus Ruas Jalan Krakatau - Ruas Jalan Tawes Kelurahan Yosorejo Kecamatan Metro Timur Kota Metro)
}

\author{
Eri Prawati ${ }^{1}$, Riski Al Fajri ${ }^{2}$ \\ Prodi Teknik Sipil Universitas Muhammadiyah Metro ${ }^{1,2}$ \\ E-mail : eri.prawati@yahoo.co.id ${ }^{1}$, riski.1996.raf@gmail.com²
}

\begin{abstract}
ABSTRAK
Bencana banjir dapat terjadi setiap saat dan sering mengakibatkan kerugian jiwa dan harta benda. Kejadian banjir tidak dapat dicegah, namun, untuk mengurangi kerugian akibat bencana tersebut perlu dipersiapkan saluran yang mampu mengaliri air dengan baik. Drainase adalah saluran untuk mengalirkan air yang berlebih pada suatu kawasan. Jika perencanaan drainase kurang baik maka akan menimbulkan genangan air di daerah sekitar saluran drainase karena tidak mampunya saluran drainase menampung debit air yang tinggi dan akan menimbulkan dampak bagi masyarakat setempat.

Pada ruas Jalan Krakatau sampai Jalan Tawes terdapat 1 saluran pembuang jenis salurannya berbentuk trapesium dengan kemiringan dasar saluran rata-rata kurang dari 1 $\%$. Saluran drainase pada ruas Jalan Cemara memiliki struktur bangunan yang kurang baik dan juga banyak terdapat sedimen yang berasal dari limbah rumah tangga ataupun sampah disekitar sehingga menyebabkan kinerja saluran tidak maksimal. Kemudian pada ruas jalan Kapten Tendean kondisi saluran cukup baik dengan tipe saluran rata-rata pasangan batu. Dilihat dari debit banjir rencana yang didapat maka dapat ditentukan dimensi saluran ekonomis untuk saluran 4 yaitu lebar dasar saluran (b) adalah $01,58 \mathrm{~m}$, tinggi muka air (h) adalah $0.79 \mathrm{~m}$, dan tinggi jagaan $(\mathrm{w})$ adalah $0.53 \mathrm{~m}$. Untuk saluran 5 lebar dasar saluran (b) adalah 2,14 m, tinggi muka air (h) adalah 1,07 m dan tinggi jagaan (w) adalah $0.36 \mathrm{~m}$. Pada saluran 6 lebar dasar saluran (b) adalah 3,20 m, tinggi muka air (h) adalah 1,60 m dan tinggi jagaan $(\mathrm{w})$ adalah $0,53 \mathrm{~m}$.
\end{abstract}

Kata Kunci : Curah hujan, Saluran, Drainase, Debit

\section{PENDAHULUAN}

Peristiwa banjir merupakan suatu indikasi dari ketidakseimbangan sistem lingkungan dalam proses mengalirkan air permukaan, dipengaruhi oleh besar debit air yang mengalir melebihi daya tampung saluran, selain debit aliran permukaan banjir juga dipengaruhi oleh kondisi daerah pengaliran dan iklim (curah hujan) setempat.

Bencana banjir merupakan fenomena alam, yang terjadi karena dipicu oleh proses alamiah dan aktivitas manusia yang tidak terkendali dalam mengeksploitasi alam. Bencana banjir dapat terjadi setiap saat dan sering mengakibatkan kerugian jiwa dan harta benda. Kejadian banjir tidak dapat dicegah, namun, untuk mengurangi kerugian akibat bencana tersebut perlu dipersiapkan saluran yang mampu mengaliri air dengan baik. Drainase adalah saluran untuk mengalirkan air yang berlebih pada suatu kawasan. Jika perencanaan drainase kurang baik maka 
akan menimbulkan genangan air di daerah sekitar saluran drainase karena tidak mampunya saluran drainase menampung debit air yang tinggi dan akan menimbulkan dampak bagi masyarakat setempat, Hal ini terjadi karena saluran drainase dibangun dan dirawat seadanya dan seakan tak perlu mendapat perhatian khusus.

Pada ruas jalan Krakatau sampai jalan Tawes Kelurahan Yosorejo, Kecamatan Metro Timur, Kota Metro telah terjadi banjir di beberapa titik jalan tersebut yang di akibatkan limpasan dari saluran drainase. Limpasan tersebut terjadi karena saluran drainase tidak mampu menampung debit air yang tinggi akibat hujan yang terjadi kurang lebih 2 jam dan menimbulkan banjir setinggi 30 - $50 \mathrm{~cm}$. Akibat banjir tersebut menyebabkan terganggunya aktifitas masyarakat disekitar ruas jalan Krakatau sampai jalan Tawes. Banyak dugaan mengenai faktor penyebab terjadinya banjir di ruas jalan krakatau sampai jalan Tawes salah satu nya karena saluran drainase yang tidak di rawat dengan baik sehingga saluran drainase tersebut tidak mampu menampung debit air yang tinggi sehingga menyebabkan limpasan air pada area sekitar saluran, dan menyebabkan banjir membuat aktifitas masyarakat terganggu,

\section{TINJAUAN PUSTAKA}

\section{Pengertian Drainase}

Mengalirkan air yang berlebihan dalam suatu konteks pemanfaatan tertentu. Drainase merupakan salah satu fasilitas dasar yang dirancang sebagai sistem guna memenuhi kebutuhan masyarakat dan merupakan komponen penting dalam perencanaan kota (perencanaan infrastruktur khususnya). Secara umum, drainase didefinisikan sebagai serangkaian bangunan air yang berfungsi untuk mengurangi atau membuang kelebihan air dari suatu kawasan atau lahan, sehingga lahan dapat difungsikan secara optimal. (Suripin, 2004).

\section{Sistem Drainase}

Sistem Drainase dapat didefinisikan sebagai serangkaian bangunan air yang berfungsi untuk mengurangi atau membuang kelebihan air dari suatu kawasan atau lahan, sehingga lahan dapat difungsikan secara optimal. Diruntut dari hulunya, bangunan sistem drainase terdiri dari saluran penerima (interceptor drain), saluran pengumpul (collector drain), saluran pembawa (conveyor drain), saluran induk (main drain), dan badan air penerima (receiving waters). Adapun Sesuai dengan cara kerjanya, Saluran drainase buatan dibedakan menjadi: (Anisah Lukman 2018).

\section{Saluran penerima (interceptor drain)}

Berfungsi sebagai pencegah terjadinya pembebanan aliran dari suatu daerah terhadap daerah lain di bawahnya. Saluran ini biasanya dibangun dan diletakkan pada bagian yang relatif sejajar dengan garis kontur. Outlet dari saluran inibiasanya terdapatdi saluran collector atau conveyor atau langsung di natural drainage/sungai alam.

\section{Saluran pengumpul (collector drain)}

Berfungsi sebagai pengumpul debit yang diperoleh dari saluran drainase yang lebih kecil dan akhirnya akan dibuang ke saluran conveyor (pembawa).

\section{Saluran pembawa (conveyor drain)}

Berfungsi sebagai pembawa air buangan dari suatu daerah ke lokasi pembuangan tanpa harus membahayakan daerah yang dilalui.

Menurut keberadaannya, sistem jaringan drainase dapat dibedakan menjadi 2 (dua), yaitu:
1) Natural
Drainage (Drainase
Alamiah)
Drainase yang terbentuk secara alami dan tidak terdapat bangunan penunjang seperti bangunan 
pelimpah,Pasangan batu/beton,goronggorong,dan lain-lain. Saluran ini terbentuk oleh gerusan air yang bergerak karena gravitasi yang lambat laun membentuk jalan air yang permanen seperti sungai. (Anonim, 1997).

2) Artificial

Drainage (Drainase

Buatan)

Dibuat oleh manusia, dimaksudkan sebagai upaya penyempurnaan atau melengkapi kekurangan-kekurangan sistem drainase alamiah dalam fungsinya membuang kelebihan air yang mengganggu. Jika ditinjau dari sistem jaringan drainase, kedua sistem tersebut harus merupakan kesatuan tinjauan yang berfungsi secara bersama. (Anonim, 1997).

Menurut fungsinya, saluran drainase dapat dibedakan menjadi:

(a) Single purpose,

yaitu saluran hanya berfungsi mengalirkan satu jenis air buangan saja. (Anonim, 1997).

(b) Multi purpose,

yaitu saluran yang berfungsi mengalirkan beberapa jenis air buangan, baik secara tercampur maupun secara bergantian. (Anonim, 1997).

Menurut konstruksinya, saluran drainase dapat dibedakan menjadi:

(1) Drainase saluran terbuka

Saluran drainase primer biasanya berupa saluran terbuka, baik berupa saluran dari tanah, pasangan batu kali atau beton. (Anonim, 1997).

(2) Drainase saluran tertutup

Pada kawasan perkotaan yang padat, saluran drainase biasanya berupa saluran tertutup. Saluran dapat berupa buis beton yang dilengkapi dengan bak kontrol, atau saluran pasangan batu kali/beton yang diberi plat tutup dari beton bertulang. Karena tertutup, maka perubahan penampang saluran akibat sedimentasi, sampah dan lain-lain tidak dapat terlihat dengan mudah. (Anonim, 1997).

\section{Bentuk Saluran Drainase}

a. Bentuk Trapesium
Umumnya digunakan pada daerah yang masih mempunyai lahan cukup luas, dan harga lahan murah, umumnya digunakan untuk saluran yang relatif besar.

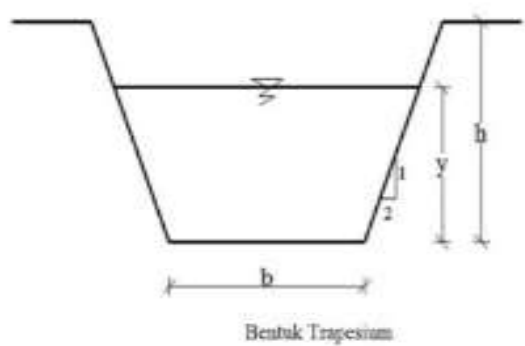

Gambar 1. Saluran Drainase berbentuk Trapesium

b. Bentuk Segi Empat

Umumnya digunakan pada daerah yang lahannya tidak terlalu lebar dan harga lahannya mahal. Umumnya digunakan untuksaluran yang relatif besar dan sedang.

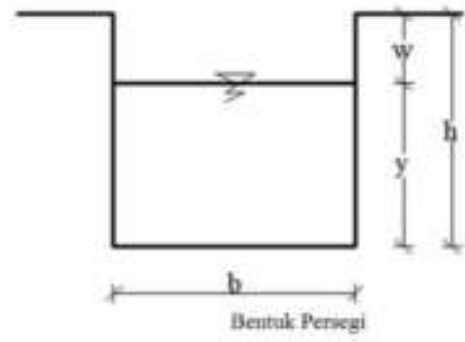

Gambar 2. Saluran Drainase berbentuk Segi empat

c. Bentuk Setengah Lingkaran

Umumnya digunakan pada saluran di lingkungan permukiman berupa saluran sekunder dan tersier.

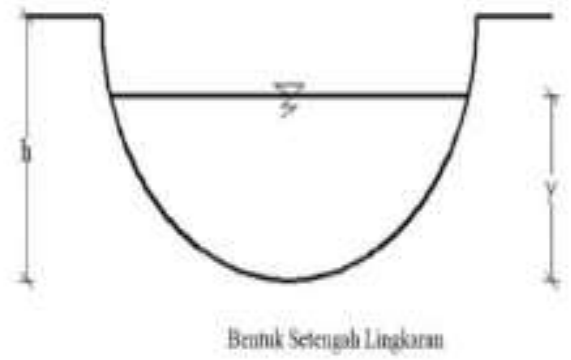

Gambar 3. Saluran Drainase berbentuk setengah lingkaran

d. Bentuk Segi Tiga

Umumnya digunakan pada daerah permukiman sebagai salurantersier. Keuntungannya dapat mengalirkan air pada debit yangkecil. Kerugiannya sulit dalam pemeliharaan. 


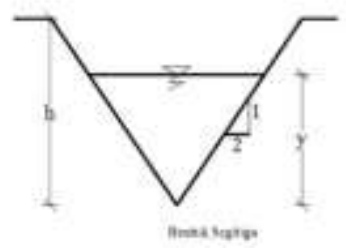

Gambar 4. Saluran Drainase berbentuk Segitiga

\section{Permasalahan Drainase dan Beberapa Gangguan Sistem Drainase}

Banyak faktor yang mempengaruhi dan perlu dipertimbangkan secara matang dalam perencanaan suatu sistem drainase yang berkelanjutan. Perencanaan tidak hanya disesuaikan dengan kondisi sekarang namun juga untuk masa yang akan datang. Permasalahan permasalahan drainase perkotaan antara lain. (Ismawan Dewansyah, 2018).

\section{a. Peningkatan Debit}

Perubahan tata guna lahan yang selalu terjadi akibat perkembangan kota dapat mengakibatkan peningkatan aliran permukaan dan debit banjir. Besar kecil aliran permukaan sangat ditentukan oleh pola penggunaan lahan, yang diekspresikan dalam koefisien pengaliran yang 20 bervariasi antara 0,10 (hutan datar) sampai 0,95 (perkerasan jalan). Hal ini menunjukkan bahwa pengalihan fungsi lahan dari hutan menjadi perkerasan jalan bisa meningkatkan debit puncak banjir sampai 9,5 kali, dan hal ini mengakibatkan prasarana drainase yang ada menjadi tidak mampu menampung debit yang meningkat tersebut.

b. Penyempitan dan Pendangkalan Saluran

Peningkatan jumlah penduduk yang sangat pesat mengakibatkan berkurangnya lahan untuk saluran drainase. Banyak pemukiman yang didirikan diatas saluran drainase sehingga aliran drainase menjadi tersumbat. Selain itu, sampah penduduk juga tidak jarang dijumpai dialiran drainase, terutama didaerah perkotaan. c. Lemahnya Koordinasi Dan

Sinkronisasi Dengan Komponen Infrastruktur Yang Lain

Hal ini dapat dilihat dari seringnya dijumpai tiang listrik atau pipa air bersih ditengah saluran drainase, yang berakibat terganggunya kelancaran aliran di drainase itu sendiri. Selain itu, seringkali penggalian saluran drainase tidak sengaja merusak prasarana yang sudah ada atau yang ditanam dalam tanah. Biasanya kesalahan ini terjadi karena tidak adanya informasi yang akurat mengenai prasarana tersebut.

\section{Penyebab Terjadinya Banjir}

Banyak faktor menjadi penyebab terjadinya banjir. Namun secara umum penyebab terjadinya banjir dapat diklasifikasikan dalam 2 kategori, yaitu banjir yang disebabkan oleh sebab-sebab alami dan banjir yang diakibatkan oleh tindakan manusia.

a. Penyebab Banjir Secara Alami

1) Curah Hujan

Indonesia mempunyai iklim tropis sehingga sepanjang tahun mempunyai dua musim yaitu musim hujan umumnya terjadi antara bulan Oktober sampai bulan Maret, dan musim kemarau terjadi antara bulan April sampai bulan September. Pada musim penghujan, curah hujan yang tinggi akan mengakibatkan banjir di sungai dan bilamana melebihi tebing sungai maka akan timbul banjir atau genangan.

2) Pengaruh Fisiografi

Fisiografi atau geografi fisik sungai seperti bentuk, fungsi dan kemiringan daerah pengaliran sungai (DPS), kemiringan Pengaruh Fisiografi. sungai, geometrik hidrolik (bentuk penampang seperti lebar, kedalaman, potonan memanjang, material dasar sungai), lokasi sungai dan lain-lain. Merupakan hal-hal yang mempengaruhi terjadinya banjir.

3) Erosi dan Sedimentasi

Erosi di DPS berpengaruh terhadap pengurangan kapasitas penampang 
sungai. Erosi menjadi problem klasik sungai-sungai di Indonesia. Besarnya sedimentasi akan mengurangi kapasitas saluran, sehingga timbul genangan dan banjir di sungai. Sedimentasi juga menjadi masalah besar pada sungaisungai di Indonesia.

4) Kapasitas Drainase yang tidak memadai

Hampir semua kota-kota di Indonesia mempunyai drainase daerah genangan yang tidak memadai, sehingga kota-kota tersebut sering menjadi langganan banjir di musim hujan.

b. Penyebab Banjir Akibat Tindakan Manusia

\section{1) Perubahan Kondisi DPS}

Perubahan DPS seperti pengundulan hutan, usaha pertanian yang kurang tepat, perluasan kota dan perubahan tataguna lainnya dapat memperburuk masalah banjir karena meningkatnya aliran banjir. Dari persamaan-persamaan yang ada, perubahan tata guna lahan memberikan konstribusi yang besar terhadap naiknya kuantitas dan kualitas banjir.

2) Kawasan kumuh

Perumahan kumuh yang terdapat di sepanjang sungai, dapat merupakan penghambat aliran. Masalah kawasan kumuh dikenal sebagai faktor penting terhadap masalah banjir daerah perkotaan.
3) Sampah

Disiplin masyarakat untuk membuang sampah pada tempat yang ditentukan tidak baik, umumnya mereka langsung membuang sampah ke sungai. Di kota-kota besar hal ini sangat mudah dijumpai. Pembuangan sampah dialur sungai dapat meninggikan muka air banjir karena menghalangi aliran.

4) Drainase Lahan

Drainase perkotaan dan pengembangan pertanian pada daerah bantuan banjir akan mengurangi kemampuan bantaran dalam menampung debit air yang tinggi.

\section{METODE PENELITIAN}

Penelitian dilakukan pada saluran drainase yang terletak pada salah satu wilayah di daerah Kota Metro Lampung yaitu Kelurahan Yosorejo Kecamatan Metro Timur dengan luas wilayah 1.22 $\mathrm{km}^{2}$. Lokasi penelitian terletak pada ruas Jalan Krakatau sampai Jalan Tawes yang berada di komplek padat penduduk. Untuk mengetahui gambaran yang lebih jelas untuk saluran drainase pada daerah yang diteliti dapat dilihat pada gambar yang menunjukan denah lokasi penelitian dan arah aliran saluran drainase.

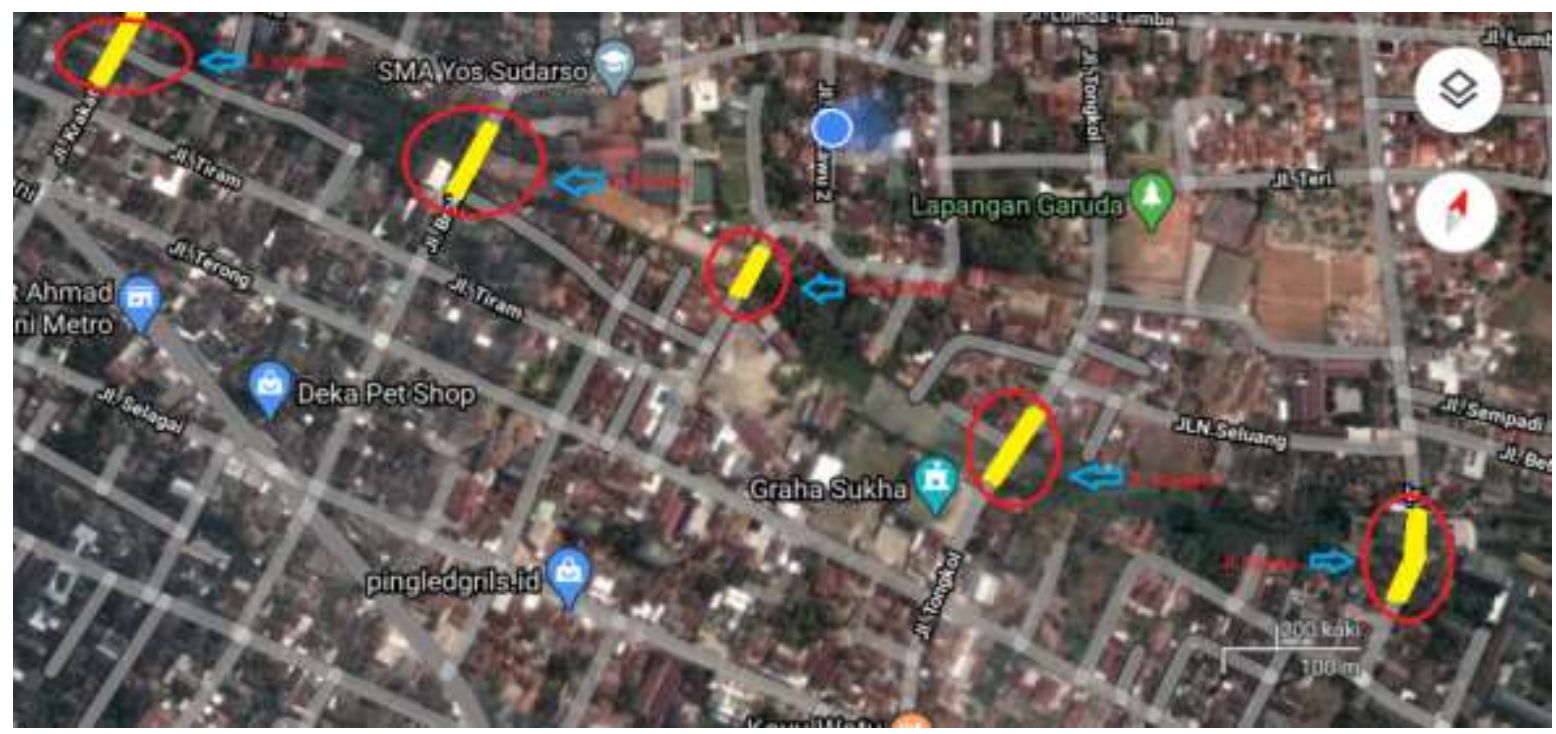

Gambar 5. Lokasi Penelitian 


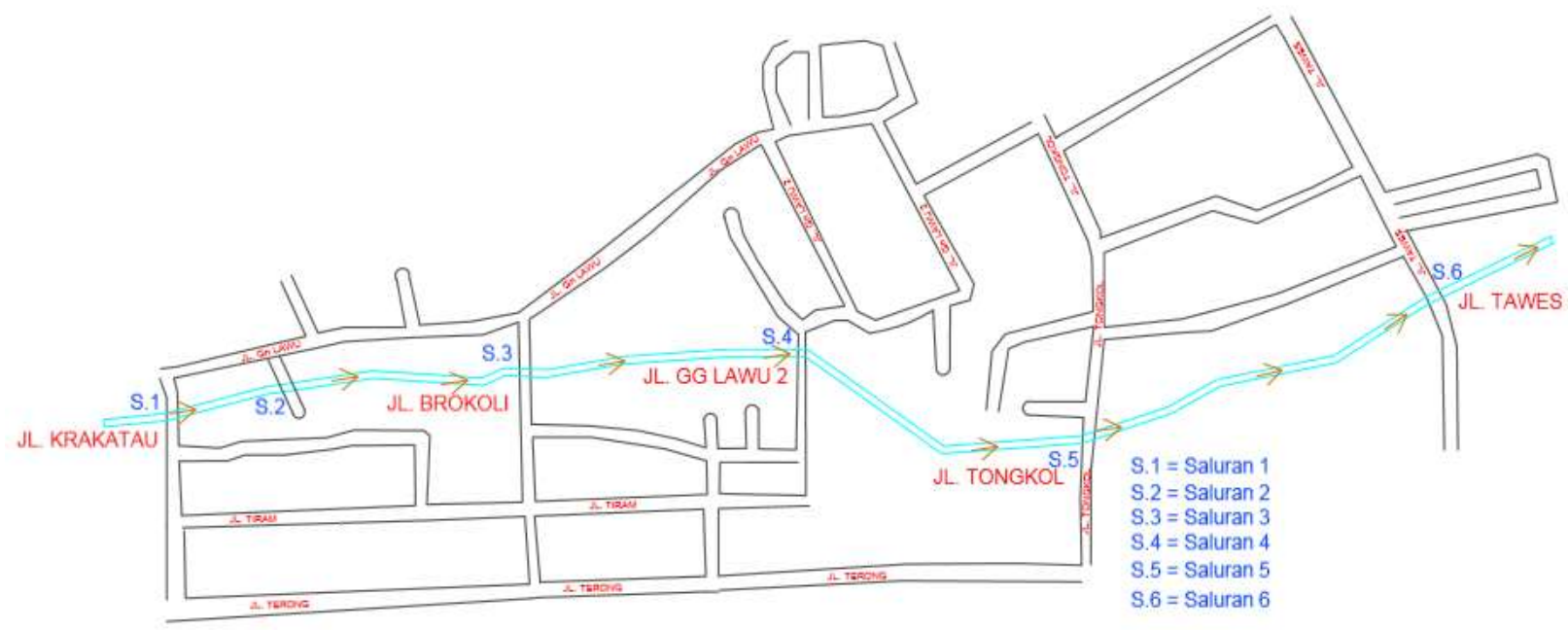

Gambar 6. Arah Aliran Saluran Drainase

a. Data Saluran Drainase

Pengamatan pada ruas jalan Krakatau sampai jalan Tawes diperoleh data saluran sebagai berikut:

Tabel 1. Data Saluran Drainase

\begin{tabular}{|c|c|c|c|}
\hline No & Saluran & $\begin{array}{c}\text { Panjang } \\
\text { (L) }\end{array}$ & $\begin{array}{c}\text { Tipe } \\
\text { Saluran }\end{array}$ \\
\hline 1 & S.1 & $0,04 \mathrm{~km}$ & $\begin{array}{c}\text { Pasangan } \\
\text { Batu }\end{array}$ \\
\hline 2 & S. 2 & $0,09 \mathrm{~km}$ & $\begin{array}{c}\text { Pasangan } \\
\text { Batu }\end{array}$ \\
\hline 3 & S.3 & $0,226 \mathrm{~km}$ & $\begin{array}{c}\text { Pasangan } \\
\text { Batu }\end{array}$ \\
\hline 4 & S. 4 & $0,225 \mathrm{~km}$ & $\begin{array}{c}\text { Pasangan } \\
\text { Batu }\end{array}$ \\
\hline 5 & S.5 & $0,247 \mathrm{~km}$ & $\begin{array}{c}\text { Pasangan } \\
\text { Batu }\end{array}$ \\
\hline 6 & S.6 & $0,315 \mathrm{~km}$ & $\begin{array}{c}\text { Pasangan } \\
\text { Batu }\end{array}$ \\
\hline
\end{tabular}

Tabel 2. Hasil Pengukuran Elevasi Saluran Drainase.

\begin{tabular}{ccccc}
\hline No & $\begin{array}{c}\text { Salu } \\
\text { ran }\end{array}$ & $\begin{array}{c}\text { Panjang } \\
(\mathbf{L})\end{array}$ & $\begin{array}{c}\text { Elevasi } \\
\mathbf{M a x} \\
\left(\mathbf{t}_{\mathbf{1}}\right)\end{array}$ & $\begin{array}{c}\text { Elevasi } \\
\text { Min }\left(\mathbf{t}_{\mathbf{2}}\right)\end{array}$ \\
\hline 1 & S.1 & $0,04 \mathrm{~km}$ & 69,856 & 68,248 \\
2 & $\mathrm{~S} .2$ & $0,09 \mathrm{~km}$ & 69,856 & 68,02 \\
3 & $\mathrm{~S} .3$ & $0,226 \mathrm{~km}$ & 68,913 & 68,060 \\
4 & $\mathrm{~S} .4$ & $0,225 \mathrm{~km}$ & 68,697 & 68,273 \\
5 & $\mathrm{~S} .5$ & $0,247 \mathrm{~km}$ & 67,898 & 67,638 \\
6 & S.6 & $0,315 \mathrm{~km}$ & 67,600 & 67,417 \\
\hline
\end{tabular}

Tabel 3. Rekapitulasi Debit Banjir Rencana

\begin{tabular}{ccccccc}
$\begin{array}{c}\text { Kala } \\
\text { Ulang } \\
\text { Tahun }\end{array}$ & S.1 & S.2 & S.3 & S.4 & S.5 & S.6 \\
\hline 2 & 0,110 & 0,3319 & 0,612 & 0,932 & 1,838 & 3,021 \\
5 & 0,147 & 0,4402 & 0,703 & 1,232 & 2,432 & 3,939 \\
10 & 0,169 & 0,5027 & 0,804 & 1,408 & 2,779 & 4,501 \\
50 & 0,222 & 0,6608 & 1,057 & 1,852 & 3,656 & 5,878 \\
100 & 0,242 & 0,7249 & 1,152 & 2,109 & 3,986 & 6,044 \\
\hline
\end{tabular}

\section{Perhitungan Debit Saluran Drainase Eksisting $\left(\mathbf{Q}_{\mathrm{s}}\right)$}

Analisis kapasitas saluran drainase eksisting dilakukan untuk mengetahui kemampuan saluran drainase dalam menampung air hujan. Berikut adalah dimensi saluran drainase eksisting dan peta situasi yang didapat dari pengukuran di lapangan.

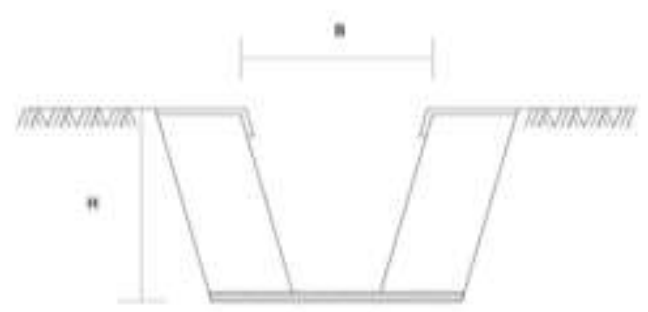

Gambar 7. Saluran Drainase Eksisting 
Tabel 4. Rekapitulasi Debit Saluran Eksisting $\left(\mathrm{Q}_{\mathrm{s}}\right)$

\begin{tabular}{|c|c|c|c|}
\hline No & Saluran & Sta & $\left(\mathbf{Q}_{\mathrm{s}}\right)$ \\
\hline 1 & S.1 & $\begin{array}{c}0+000 \\
- \\
0+040\end{array}$ & $5,8090 \mathrm{~m}^{3} / \mathrm{dt}$ \\
\hline 2 & S.2 & $0+000$ & $4,8914 \mathrm{~m}^{3} / \mathrm{dt}$ \\
\hline & & $\begin{array}{l}0+090 \\
0+000\end{array}$ & \\
\hline 3 & S.3 & & $2,5246 \mathrm{~m}^{3} / \mathrm{dt}$ \\
\hline 4 & S.4 & $\begin{array}{c}0+000 \\
- \\
0+225\end{array}$ & $1,2840 \mathrm{~m}^{3} / \mathrm{dt}$ \\
\hline 5 & S.5 & $\begin{array}{c}0+000 \\
- \\
0+247\end{array}$ & $1,0270 \mathrm{~m}^{3} / \mathrm{dt}$ \\
\hline 6 & S.6 & $\begin{array}{c}0+000 \\
- \\
0+315 \\
\end{array}$ & $1,4577 \mathrm{~m}^{3} / \mathrm{dt}$ \\
\hline
\end{tabular}

\section{Perbandingan Nilai Debit Rancangan (Qr) Dan Debit Saluran Eksisting (Qs)}

Hasil perhitungan debit saluran eksisting menunjukkan kemampuan saluran drainase dalam mengalirkan debit, sehingga dapat dilakukan analisis terhadap kapasitas tampungan saluran yang tersedia mampu atau tidak dalam mengalirkan debit saat maksimum. Hasil analisis kapasitas saluran drainase yang dilakukan dengan perbandingan nilai Qr dan Qs pada masing - masing saluran. dan Qr

Tabel 5. Perbandingan Nilai Qs

\begin{tabular}{|c|c|c|c|c|c|c|}
\hline \multirow{3}{*}{ uran } & \multirow{3}{*}{ Sta } & \multicolumn{5}{|c|}{ Debit Rancangan Periode } \\
\hline & & \multirow[t]{2}{*}{$\left(Q_{s}\right)$} & \multicolumn{3}{|c|}{ Ulang (Qr) } & netrala \\
\hline & & & 2 & 5 & 10 & \\
\hline. .1 & $0+000-0+040$ & $5,8090 \mathrm{~m}^{3} / \mathrm{dt}$ & 0,1104 & 0,1468 & 0,1688 & Saluran \\
\hline i.2 & $0+000-0+090$ & $4,8914 \mathrm{~m}^{3} / \mathrm{dt}$ & 0,3319 & 0,4402 & 0,5027 & Saluran \\
\hline i.3 & $0+000-0+226$ & $2,5246 \mathrm{~m}^{3} / \mathrm{dt}$ & 0,6118 & 0,7034 & 0,8037 & Saluran \\
\hline$i .4$ & $0+000-0+225$ & $1,2480 \mathrm{~m}^{3} / \mathrm{dt}$ & 0,9317 & 1,2323 & 1,4083 & Saluran Tid \\
\hline i.5 & $0+000-0+247$ & $1,0270 \mathrm{~m}^{3} / \mathrm{dt}$ & 1,8384 & 2,4318 & 2,7793 & Saluran Tid \\
\hline & $0+000-0+3$ & $1,4577 \mathrm{~m}^{3} / \mathrm{dt}$ & $\langle<|$ & 3.9391 & 4,5005 & Saluran Tid \\
\hline
\end{tabular}

Tabel 6. Rekapitulasi Perhitungan Dimensi Saluran Ekonomis

\begin{tabular}{|c|c|c|c|c|c|c|c|c|c|}
\hline \multirow{3}{*}{ lluran } & \multirow{3}{*}{ L } & \multirow{3}{*}{$S$} & \multicolumn{3}{|c|}{ Debit Banjir Rencana } & \multirow{2}{*}{\multicolumn{4}{|c|}{ Dimensi Saluran Rer }} \\
\hline & & & & (Qr) & & & & & \\
\hline & & & 2 & 5 & 10 & $\mathrm{~h}$ & b & w & $A$ \\
\hline$\overline{S .4}$ & $225 \mathrm{~m}$ & 0.0018 & 0,9317 & 1,2323 & 1,4083 & 0.79 & 1,58 & 0.53 & $\overline{1, c}$ \\
\hline S.5 & $247 \mathrm{~m}$ & 0.0011 & 1,8384 & 2,4318 & 2,7793 & 1,07 & 2,14 & 0,36 & $2, c$ \\
\hline S.6 & $315 \mathrm{~m}$ & 0.0006 & 3,0213 & 3,9391 & 4,5005 & 1,60 & 3,20 & 0,53 & 5,1 \\
\hline
\end{tabular}

Keterangan:

$\mathrm{L} \quad=$ Panjang saluran $(\mathrm{m})$

$\mathrm{S}=$ Kemiringan saluran $(\mathrm{m})$

$\mathrm{Qr}=$ Debit banjir rencana $\left(\mathrm{m}^{3} / \mathrm{dtk}\right)$

$\mathrm{h}=$ Tinggi muka air (m)

$\mathrm{W}=$ Tinggi jagaan $(\mathrm{m})$

A = Luas penampang basah $\left(\mathrm{m}^{2}\right)$

$\mathrm{P} \quad=$ Keliling penampang bassah $(\mathrm{m})$

Pada analisis kapasitas saluran drainase diatas menggunakan data curah hujan 10 tahun terakhir dengan analisa frekuensi hujan menggunakan metode distribusi Log Person III dan metode Log normal 2 parameter untuk mendapatkan nilai sesuai persyaratan jenis sebara dan juga mendapatkan nilai curah hujan rencana tiap tahun. Perhitungan debit banjir rencana pada analisis saluran drainasenya menggunakan metode Weduwen. Evaluasi kapasitas saluran drainase di daerah penelitian dilakukan dengan pertimbangan perhitungan parameter hujan dan kondisi lahan pada saat perencanaan saluran drainase. Intensitas hujan rancangan dan penggunaan lahan mengalami perubahan seiring kondisi saat ini.

Hasil perhitungan kapasitas saluran drainase diatas memperlihatkan bahwa terdapat saluran yang tidak aman karena debit saluran eksisting (Qs) lebih kecil dari debit banjir rencana (Qr) yaitu pada saluran 4, saluran 5 dan saluran 6 sehingga saluran tesebut perlu untuk diredesain. Kapasitas saluran tidak aman pada saluran terjadi pada kala ulang 10 tahun. Untuk kapasitas saluran tidak 
aman saluran 5 terdapat pada kala ulang 2, 5 dan 10 tahun. Untuk kapasitas tidak aman saluran 6 terdapat pada kala ulang2, 5 dan 10 tahun. Untuk kapasitas saluran drainase lainnya sudah aman tetapi kondisinya perlu diperhatikan terutama pada saluran 1, 2, dan 3. Pada saluran tersebut banyak terdapat sedimen yang dapat mengurangi kapasitas dari saluran itu sendiri sehingga dapat menyebabkan genangan air di sekitar saluran. Perlu adanya kesadaran masyarakat untuk perawatan guna menanggulangi terjadinya genangan air disekitar saluran tersebut. Untuk perhitungan redesain saluran 4, 5, 6 dan dapat ditinjau dari debit banjir rencana dan elevasi saluran yang telah dihitung sebelumnya sehingga dapat dengan mudah menentukan dimensi saluran ekonomis yang sesuai dengan debit rencananya.

\section{KESIMPULAN}

1. Pada ruas Jalan Krakatau sampai Jalan Tawes terdapat 1 saluran pembuang yang mana jenis salurannya berbentuk trapesium dengan kemiringan dasar saluran rata-rata kurang dari $1 \%$. Saluran drainase pada ruas Jalan Cemara memiliki struktur bangunan yang kurang baik dan juga banyak terdapat sedimen yang berasal dari limbah rumah tangga ataupun sampah disekitar sehingga menyebabkan kinerja saluran tidak maksiimal. Kemudian pada ruas jalan Kapten Tendean kondisi saluran cukup baik dengan tipe saluran rata-rata pasangan batu.

2. Arah aliran saluran Pembuang pada ruas jalan krakatau sampai jalan Tawes yang mana akhir dari saluran mengarah ke sungai Way Batanghari yang berada di bagian hilir saluran.

3. Dari perhitungan kapasitas saluran eksisting pada ruas jalan Krakatau dan Jalan Tawes terdapat 3 saluran yang tidak mampu menahan debit banjir rencana yaitu pada saluran 4, 5 dan 6 . Pada saluran tersebut kapasitas eksisting (Qs) tidak lebih besar dari debit banjir rencana (Qr) yang telah dihitung berdasarkan data curah hujan 10 tahun terakhir sehingga perlu untuk diredesain.

4. Dilihat dari debit banjir rencana yang didapat maka dapat ditentukan dimensi saluran ekonomis untuk saluran 4 yaitu lebar dasar saluran (b) adalah $01,58 \mathrm{~m}$, tinggi muka air (h) adalah $0.79 \mathrm{~m}$, dan tinggi jagaan $(\mathrm{w})$ adalah $0.53 \mathrm{~m}$. Untuk saluran 5 lebar dasar saluran (b) adalah 2,14 m, tinggi muka air (h) adalah 1,07 $\mathrm{m}$ dan tinggi jagaan (w) adalah $0.36 \mathrm{~m}$. Pada saluran 6 lebar dasar saluran (b) adalah 3,20 m, tinggi muka air (h) adalah 1,60 $\mathrm{m}$ dan tinggi jagaan (w) adalah $0,53 \mathrm{~m}$.

\section{DAFTAR PUSTAKA}

Ariffin Muhamad, 2018 Evaluasi Kinerja Sistem Drainase Perkotaan di Wilayah Purwokerto : Universitas Cokroaminoto Yogyakarta

Arikunto Suharsimi, 1998 Prosuder Penelitian Suatu Pendekatan Praktek Jakarta: PT. Rineka Cipta

Fitri Annisaa, dkk, Evaluasi Sistem Drainase di Daerah Simo Gunung, Simo Mulyo Barat, Simo Mulyo, Darmo Satelit, dan Darmo Indah Yang Berada di Surabaya Barat: Universitas Brawijaya

H.A. Hasmar Halim, 2011 Drainase Terapan Yogyakarta : UII Pres

H. Mulyanto R, 2012 Penataan Drainase Perkotaan Semarang : Graha Ilmu

Joesron Loebis, Ir M. Eng 1987 Banjir Rencana Untuk Bangunan Air Jakarta. Badan Penerbit Pekerjaan Umum

Lukman Anisah 2018 Evaluasi Sistem Drainase di Kecamatan Helvetia Kota Medan : Universitas Islam Sumatra Utara 
Limantara Lily Montarcih, Dr. Ir. M. Sc 2010 Hidrologi Praktis. Lubuk Agung. Bandung

Marcos, dkk, 2014 Evaluasi Sistem Drainase Terhadap Genangan Di Kecamatan Wates Kabupaten Blitar : Universitas Tribhuwana Tunggadewi

Notodihardjo M, 1998 Drainase Perkotaan. Universitas

Tarumanegara : Jakarta

Prawati Eri, 2019 Analisis Hujan Ratarata Dalam Menentukan Debit Banjir Rancangan pada DAS Blambangan Kabupaten Banyuwangi : Jawa timur

Restiani Esi, dkk, Analisis Kinerja Sistem Draninase Kelurahan Kuto Panji Kecamatan Belingu : Universitas Bangka Belitung

Sn, 1997. Drainase Perkotaan. ISBN : 979-8382-49-8. Gunadarma

Supriono Bambang, dkk, 2018 Evaluasi Saluran Drainase Pada Jalan Kenanga Di Kelurahan Mulyojati Kecamatan Metro Barat : Universitas Bandar Lampung

Suripin, Dr. Ir M. Eng 2004 Sistem Drainase Perkotaan yang Berkelanjutan. Yogyakarta. 